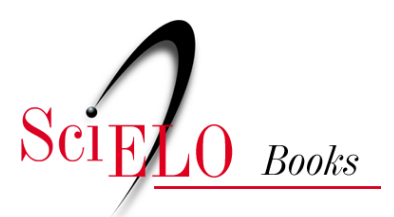

\title{
Museu Fritz Plaumann
}

\author{
José Carlos Radin \\ Gentil Corazza
}

\section{SciELO Books / SciELO Livros / SciELO Libros}

RADIN, J.C., and CORAZZA, G. Museu Fritz Plaumann. In: Dicionário histórico-social do Oeste catarinense [online]. Chapecó: Editora UFFS, 2018, pp. 121-124. ISBN: 978-85-64905-65-8. https://doi.org/10.7476/9788564905658.0029.

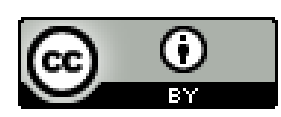

All the contents of this work, except where otherwise noted, is licensed under a Creative Commons Attribution 4.0 International license.

Todo o conteúdo deste trabalho, exceto quando houver ressalva, é publicado sob a licença Creative Commons Atribição $\underline{4.0}$.

Todo el contenido de esta obra, excepto donde se indique lo contrario, está bajo licencia de la licencia $\underline{\text { Creative Commons }}$ Reconocimento 4.0. 


\section{Museu Fritz Plaumann}

O Museu Entomológico Fritz Plaumann está situado no distrito de Nova Teutônia, interior do município de Seara, em Santa Catarina. Foi criado pelo entomólogo alemão Fritz Plaumann, ao longo de quase todo o século XX. Seu acervo é o resultado de aproximadamente 70 anos de trabalho de coleta e classificação de insetos da fauna local, especialmente da área de floresta do Oeste catarinense, embora inclua exemplares da floresta atlântica dos três Estados sulinos, de São Paulo e mesmo da floresta amazônica (SILVA, 1998). A coleção de insetos do museu tem em torno de 73.000 exemplares, de 9.601 espécies, representando 19 ordens de espécies, 328 famílias e 2.219 gêneros. Cerca de 1.500 dessas espécies, antes desconhecidas da ciência, foram descobertas por Plaumann. Muitas delas não mais existem na natureza. Seu trabalho foi reconhecido no mundo inteiro e ele se tornou um renomado cientista mundial. Cerca de 150 das novas espécies descobertas por ele foram batizadas com o seu próprio nome. Em 1985, Plaumann obteve a Medalha do Mérito Universitário da Universidade Federal de Santa Catarina e, em 1991, recebeu a Grã-Cruz do Mérito Científico, a mais alta condecoração do campo da ciência da Alemanha. O Museu Fritz Plaumann é o maior museu entomológico da América Latina, que atualmente pertence à Prefeitura Municipal de Seara.

Fritz Plaumann nasceu em Eylau, na Prússia Oriental, onde hoje é a Lituânia, em 02 de abril de 1902 e morreu em 1994, aos 92 anos. Chegou ao Brasil com seus pais, Friederich e Hulde, em 1924, quando tinha 22 anos e se instalou próximo ao distrito de Nova Teutônia, no município de Seara. A viagem de navio partiu da Alemanha, em $1^{\circ}$ de outubro de 1924 e terminou no Porto de Rio Grande, algumas semanas depois. De Rio Grande, a família foi de trem até Santa Maria e, depois, até a cidade de Itá, em Santa Catarina, seguindo de carroça até a vila de Nova Teutônia, onde a família fixou residência. No início, Fritz trabalhou como agricultor, fotógrafo e comerciante. Depois, foi professor de alemão e português na escola da comunidade local. Fritz casou com a alemã Clarissa Links, em 1954. Eles não tiveram filhos 
e adotaram Gisela Germandorf como filha. Mas como muitos outros imigrantes da época, Clarissa não resistiu viver muito tempo naquelas condições e, em 1966, decidiu voltar para a Alemanha. Em 1972, Fritz assumiu a tutela da jovem Edeltraud Gomman, que se tornou, depois, sua principal ajudante no preparo dos insetos para a sua classificação. Sua mãe morreu em 1924 e seu pai, em 1928.

Logo após sua chegada ao Brasil, em $1^{\circ}$ de janeiro de 1925, Fritz inicia suas pesquisas na região, como declara em seu diário: "O dia primeiro de janeiro de 1925 foi um dos mais importantes da minha vida. Nesse dia foi lançada por mim, metaforicamente, a pedra fundamental para todas as minhas pesquisas aqui no Brasil" (SPESSATO, 2001). Aquela era, sem dúvida, uma atitude muito ambiciosa, se considerarmos a grandiosidade da obra que estava de fato iniciando, em condições precárias e o desconhecimento quase completo que tinha da região. Suas pesquisas iniciadas naquele ano de 1925 só terminam com sua morte, em 1994.

Fritz Plaumann, mesmo vivendo grande parte do tempo na floresta caçando insetos, esteve muito integrado com a comunidade de Nova Teutônia. Desde os primeiros anos procura integrar-se na vida daquela pequena comunidade, participando de seus principais eventos e auxiliando as famílias em casos de enfermidades. Muitas vezes, era chamado, até para a realização de cerimônias fúnebres. Em 1926, decorridos menos de dois anos de sua chegada, participa da construção de uma escola, da qual se torna o primeiro professor, conforme ele próprio narra em seu diário: “Domingo, 17/07/1927. Na assembleia de nossa comunidade fui eleito, com nove votos contra um, para professor da escola particular de Nova Teutônia, para ensinar nas línguas alemã e portuguesa" (SPESSATO, 2001). No mesmo diário, narra sua emoção ao terminar aquela gratificante experiência, que durou até 1932: "Porém, no fim, quando acompanhava com o violino o canto dos alunos pela última vez e a despedida, isso não passou sem emoção. Sempre tinha me dado muito bem com os alunos, não havia ninguém que me aborrecesse de propósito." (SPESSATO, 2001).

Ao pisar aquele solo do Oeste catarinense, Fritz mostra-se deslumbrado com a grande biodiversidade que encontrou no local. Sua 
curiosidade científica, no entanto, não nasceu naquele momento, pois vinha sendo alimentada desde sua infância pelo seu pai, que lhe comprava livros sobre astronomia, botânica, zoologia e outras áreas do conhecimento. Por esse motivo, ele conta que seus colegas o apelidaram de "pesquisador", ainda durante seus estudos básicos na Alemanha. E ele se tornou, de fato, um grande e renomado pesquisador. Sempre foi metódico e meticuloso. Desde os primeiros dias, depois de sua chegada ao Brasil, começou a fazer anotações em seus cadernos sobre a meteorologia, a direção dos ventos e as precipitações pluviométricas, mas especialmente sobre a fauna e a flora da região do Alto Uruguai Catarinense. Em sua coleção, encontram-se insetos coletados desde o início de seus trabalhos, na década de 1930, até o final de sua vida.

No entanto, o desenvolvimento de suas pesquisas não dependia apenas do seu trabalho de coleta e classificação dos insetos, mas também dos inúmeros contatos que mantinha com cientistas e instituições nacionais e estrangeiras. Além das cartas que escrevia, Plaumann enviava exemplares de insetos através do posto dos correios da comunidade de Itá, localidade mais próxima de sua residência (LUBENOW, 2013). Os primeiros contatos com instituições brasileiras foram feitos com cientistas do Jardim Botânico do Rio de Janeiro e do Instituto Butantã de São Paulo. Com este último, inicia ainda no ano de 1927, os contatos para o recebimento de soro contra a mordida de cobras e de aparelhos para capturá-las e enviá-las para os laboratórios do Instituto, em São Paulo. Seus contatos com pesquisadores estrangeiros também não se fizeram esperar. Ainda no ano 1933, anotava em seu diário: "Já recebia de especialistas as primeiras identificações. O especialista da família Gyrinidae, senhor Ochs, escrevia-me contando que encontrara uma nova, em homenagem ao coletor: "Gyretes plaumanni”. (SPESSATO, 2001). No ano de 1934, Fritz começou a corresponder-se com o entomologista alemão, Ferdinand Nevermann e com o Dr. O. Lundblad, diretor da Naturhistoriska Riksmuseum de Estocolmo, que analisou mais de uma centena de espécies novas colecionadas por Fritz Plaumann. Esse intercâmbio com aproximadamente 40 cientistas do mundo inteiro manteve-se praticamente até sua morte, em 1994. Paul Anaud Jr, curador e presidente da Californian Academy 
of Sciences, com quem Friz Plaumann se correspondia, declarou que Fritz Plaumann foi o maior descobridor e colecionador de insetos da América Latina, no século XX. Suas correspondências foram interrompidas apenas durante a Segunda Guerra Mundial. Grande parte de suas pesquisas são relatadas em seu alentado livro de 379 páginas, publicado em alemão, em 1947, com o sugestivo título "Die Enstehung des Lebens", que significa "A formação da vida".

\section{REFERÊNCIAS}

LUBENOW, Aline M. Fritz Plaumann: um entomólogo em construção no sertão catarinense (1924-1945). XXVII Simpósio Nacional de História Natal, julho de 2013.

MUSEU FRITZ PLAUMANN. Disponível em: <www.

museufritzplaumann.ufsc.br>.

SILVA, Rogério R. da. A coleção entomológica do Museu Fritz Plaumann.

Biotemas, 11 (2), 1998.

SPESSATTO, Mary Bortolanza. (Org.). O diário de Fritz Plaumann.

Chapecó: Argos, 2001 